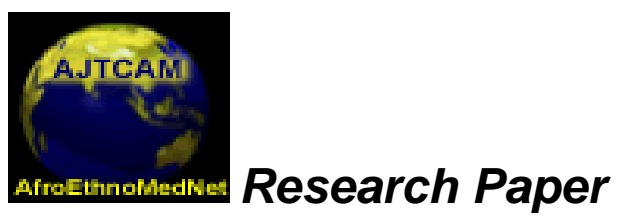

Afr. J. Traditional, Complementary and Alternative Medicines

www.africanethnomedicines.net

ISSN 0189-6016@2008

\title{
PATIENTS CONSULTING TRADITIONAL HEALTH PRACTIONERS IN THE CONTEXT OF HIV/AIDS IN URBAN AREAS IN KWAZULU-NATAL, SOUTH AFRICA
}

\author{
Karl Peltzer $^{\mathrm{a}}$ and Nolwandle Mngqundaniso ${ }^{\mathrm{b}}$
}

${ }^{a}$ Social Aspects of HIV/AIDS and Health, Human Sciences Research Council, Pretoria, South Africa \& Department of Psychology, University of the Free State, Bloemfontein, South Africa. ${ }^{\mathbf{b}}$ Human Sciences Research Council, Pretoria, South Africa.

*Email: kpeltzer@hsrc.ac.za

\begin{abstract}
The purpose of this study is to assess patients consulting full-time traditional health practitioners (THPs) and the practice of THPs after they had been trained on Human Immunodeficiency Virus (HIV)/ Sexually Transmitted Infections (STI) prevention and care. The sample included 222 patients interviewed when exiting a THP's practice $(\mathrm{n}=17)$ in purposefully chosen two urban sites in KwaZulu-Natal. Results indicate that at post training evaluation the majority of the THPs were involved in HIV/STI management and most had low levels of HIV risk practices at the workplace. Major self-reported reasons for consulting the THP included a complex of supernatural or psychosocial problems, chronic conditions, acute conditions, generalized pain, HIV and other STIs. Overall, patients including HIV positive ( $\mathrm{n}=18)$ patients had moderate knowledge of Antiretroviral Therapy (ART). A number of HIV positive patients were using traditional medicine and ART concurrently, dropped out of ART because of side effects and were using traditional medicine for HIV.
\end{abstract}

Key words: Patients, traditional health practitioners, HIV/AIDS management, KwaZulu-Natal, South Africa

\section{Introduction}

As in the rest of sub-Saharan Africa, in South Africa, 80-85\% of Black South African people are estimated to make use of traditional healers' services in both rural and urban areas (UNAIDS, 2006). Traditional healers tend to be the first 'professionals' consulted by people with a sexually transmitted disease, including Human Immunodeficiency Virus (HIV). Healers are more easily accessible geographically and provide a culturally accepted treatment. They have credibility, acceptance and respect among the population they serve, and thus form a critical part of the health-care delivery system. Traditional medicine practices differ according to culture, location and category of healer (UNAIDS, 2006). Historically, the lack of Western-trained health practitioners in South Africa kept the debate about collaboration going. Once a primary health-care policy emphasizing self-reliance and sustainability for resource-poor areas was put in place, traditional health practitioners seemed like a good group to train and include into the formal health sector. Practice has proven to be much more complex, both legally and ethically. The formal medical sector requires minimum professional standards and regards Western-based or modern practices as superior. On the other hand, traditional health practitioners protect their intellectual property for fear that one day they would have to buy back their own products in fancy wrapping. Thus, the battle is far from being over. The HIV epidemic has brought the idea of collaboration very much to the forefront again. The epidemic is expanding and people are living in a crisis mode. The result is the formation of groups and small projects that do not have the power or resources to influence the political discussions surrounding HIV, but instead focus on the immediate needs of the people (UNAIDS, 2006). 
Traditional health practitioners who practice in South African can broadly be grouped into three types; the traditional doctor or inyanga who is typically male and uses herbal and other medicinal preparations for treating disease (or herbalist); the isangoma (Zulu) or diviner, usually a woman who operates within a traditional religious supernatural context and acts as a medium with the ancestral shades; and the faith healer who integrates Christian ritual and traditional practices (Freeman and Motsei, 1992). Many South African patients consult traditional health practitioners as a first effort to remedy ailments (Louw and Pretorius, 1995). For example, among 104 Black Africans sampled from the general public in Limpopo Province South Africa that $68 \%$ sought medical treatment for their last illness, followed by the herbalist (19\%) for minor and chronic conditions, the diviner (9\%), and faith healer (4\%) (Peltzer, 2000). Traditional health practitioners seem to be consulted often for the treatment of Sexually Transmitted Infections (STIs) such as Tshofela/drop (gonorrhea), Thosola (syphilis), and assumed HIV/Acquired Immune Deficiency Syndrome (AIDS) in rural (Peltzer, 1998) and urban areas (Peltzer, 2001). In a community survey among rural adult South Africans it was found that of those who reported to have had a STI in the past 12 months, 36\% had consulted traditional health practitioners for treatment (Peltzer, 2003). Wilkinson and Wilkinson (1998) found that, among 360 patients presenting with STIs in a primary care clinic in KwaZulu-Natal, 14\% had sought care for their previous illness from a traditional health practitioner. Persons may consult traditional health practitioners for the treatment of STIs because they provide client-centered and personalized health care that is tailored to meet the needs and expectations of their patients, paying special respect to social and spiritual matters (King and Homsy, 1997).

The South African HIV prevalence amongst adults (15-49 years) is estimated to be $16 \%$ nationally and $21 \%$ in KwaZulu-Natal province (Shisana et al., 2005). King and Homsy (1997) found that experiences across African countries show that modern and traditional care systems are not incompatible. Collaborations among traditional and modern providers can create complementary systems that are of greater benefit to patients and communities. In Africa traditional medicines and natural health products are often used as primary HIV treatment and as therapy for HIV-related symptoms including dermatological disorders, nausea, depression, insomnia, and weakness (Mills et al., 2005).

According to the (South African) Department of Health (2004) the continuum of care developed for the HIV and AIDS care and treatment program should involve traditional health practitioners as an essential and irreplaceable component of the comprehensive care provided. Moreover, traditional health practitioners can enhance the implementation of the antiretroviral therapy component of this plan by mobilizing communities, drawing patients into testing programs, promoting adherence to drug regimens, monitoring side effects, sharing their expertise in patient communications with biomedical practitioners, and vice versa, and continuing their acknowledged mission in improving patient well-being and quality of life. Traditional health practitioners tend to adopt a more holistic approach to health promotion and disease management, an approach that is more appropriate to the problem of immune deficiency wherein virologic assaults upon the immune system are compounded by immune exhaustion from concomitant infections, psychological stress such as that due to social isolation, undernutrition, alcohol abuse, and behaviors that compromise immune recovery such as repeat exposure to HIV and sexually transmitted infections. A holistic approach to living with HIV and AIDS is known to be a key factor for success in living a longer, healthy life with the syndrome (ibid.). Research should be conducted on how traditional health practitioners (especially those who are practicing full-time) could fulfill their role in the management of HIV, other STIs and family planning.

The purpose of this study is to assess demographic and illness-specific characteristics of patients consulting full-time traditional health practitioners and the practice of THPs regarding promoting information and methods for HIV prevention, care and ART adherence and HIV prevention information to their clients after THPs had been trained on HIV/STI prevention and care.

\section{Method \\ Sample and procedure}

The sample included 222 patients interviewed when exiting a traditional health practitioners practice $(\mathrm{n}=17)$ in purposefully chosen urban sites (Durban and Pietermaritzburg) in KwaZulu-Natal. Durban (population of 3.2 million, 2001 Census) and Pietermaritzburg (population of 521,805) are the two largest cities in the province of KwaZulu-Natal. The THPs' HIV/AIDS provincial coordinator and her assistants identified the traditional health practitioners to be included in Durban (from the southern suburbs of Umlazi and Isipingo, and central suburbs of Mayville and The Berea) and Pietermaritzburg (from the suburbs of Imbali and Northdale). Once identified, study staff approached individuals to determine eligibility. Eligibility criteria were, recognition as a traditional health 
practitioner by the council, having a full-time practice in the community (seeing at least 20 patients per months), having attended an HIV/AIDS training workshop of three and more days (which has been described elsewhere: Peltzer et al., 2006a), to have at least 10 clients interviewed at their practice, and to be interviewed themselves.

Following the recruitment of THPs, a trained interviewer visited the healer's surgery and conducted interviews with at least 10 patients exiting the healer's practice. Interviewers had been trained for two days in research interviews. Eligibility criteria for clients were: at least 18 years old. Eligible participants were invited to a private area for the exit interview. The THP would explain to his/her client about the study. After consulting the THP, the client was referred to the reseacher. Patients were interviewed in a private place in the practice area by external interviewers.

The researchers explained the study and if the client agreed to participate, he/she would then sign an informed consent form. The study was approved by the Human Sciences Research Council Ethics Committee (Clearance no REC 2/12/11/02), the provincial Health Department in KwaZulu-Natal and the traditional health practitioner's Council in KwaZulu-Natal. Questionnaires were interview-administered in Zulu by three researchers (NM), one traditional health practitioner and one professional nurse trained in interview administration of this interview schedule. Questionnaires had been translated from English to Zulu by one and back translated by another researcher.

\section{Measure}

A semi-structured questionnaire was developed from the literature and previous research (Desclaux et al., 2004 ; Green, 1994; King and Homsy, 1997; Nachega et al. 2005; Peltzer, 1998; Peltzer et al., 2006b; Somsé et al., 1998; UNAIDS, 2002) for a) traditional health practitioners including demographics, practice characteristics, HIV and STI management, HIV risk practices and HIV treatment-related knowledge, and for b) patients consulting the THP including demographics, reasons for consultation, symptom presentation, health seeking behaviour, and HIV treatment-related knowledge. Response options for HIV treatment-related knowledge were "yes," "no," or "don't know" ("don't know" responses were keyed as incorrect responses), while response options for all other questions were "yes" or "no".

\section{Data analysis}

Quantitative measures are presented as descriptive statistics using SPSS version 14.0. Qualitative data, such as responses to open-ended questions were content analysed.

\section{Results \\ Demographics}

All patients $(n=222)$ and all but one traditional health practitioners $(n=17)$ participated in the study. Six of the THPs were herbalists, 5 diviners and 6 diviner-herbalists. Most traditional health practitioners (55.4\%) indicated that their training had lasted for more than a year, while $44.2 \%$ had less than one year training. All healers were fulltime traditional health practitioners and were registered with the traditional health practitioner's council; 12 see on average more than 40 patients a month, while 5 see on average 20-40 patients a month. All had received HIV/AIDS training of three and more days. Patient demographics showed that they were mostly women $(80 \%)$, Zulu by ethnicity (97\%), between 18 to 45 years old $(81.5 \%)$, and most had Grade 9 and more education ( $81 \%)$, and healers' demographics show that most were women (65\%), between 36 to 55 years $(57.2 \%)$ and $53 \%$ had more than Grade 8 education (see Table 1). Patients were asked about how long it took them to get to the THP, for $118(53.2 \%)$ it took 30 mins or less, while for $104(46.8 \%)$ patients it took more than 30 mins to arrive at the THP surgery.

\section{HIV/STI management by THP}

At post training evaluation the majority of the THP knew and improved knowledge of where to obtain VCT. Nine in ten of the THP indicated that they had referred a patient for HIV testing in the past three months. The post intervention evaluation of the THP found that 60 to $89 \%$ conducted HIV/STI risk behavior assessment in the past three months, integrated partner referral in their STD management, conducted HIV/STI risk reduction counselling in the past three months, had distributed condoms to their patients in the past three months, conducted 
community HIV/AIDS/STI education, and had been keeping record of their patients in the past three months (Table 2).

Table 1: Patients' and healer's demographics

\begin{tabular}{|c|c|c|c|}
\hline & \multicolumn{2}{|c|}{ Patients $(n=222)$} & \multirow{2}{*}{$\begin{array}{l}\begin{array}{l}\text { Healers } \\
(\mathrm{n}=17)\end{array} \\
\mathrm{N}\end{array}$} \\
\hline & $\mathrm{N}$ & $\%$ & \\
\hline Sex & & & \\
\hline Male & 45 & 20.3 & 6 \\
\hline Female & 177 & 79.7 & 11 \\
\hline \multicolumn{4}{|l|}{ Urban location } \\
\hline Pietermaritzburg & 106 & 47.7 & 7 \\
\hline Durban (eThekwini) & 116 & 52.3 & 10 \\
\hline $18-25$ years & 50 & 22.5 & 0 \\
\hline $26-35$ years & 82 & 36.9 & 2 \\
\hline $36-45$ years & 49 & 22.1 & 4 \\
\hline $46-55$ years & 12 & 5.4 & 4 \\
\hline $56-65$ years & 10 & 4.5 & 2 \\
\hline $66-75$ years & 9 & 4.1 & 2 \\
\hline \multicolumn{4}{|l|}{ Race/Ethnicity } \\
\hline Zulu & 215 & 96.8 & 17 \\
\hline Other (Coloured, Indian or Asian) & 6 & 3.2 & \\
\hline \multicolumn{4}{|l|}{ Education } \\
\hline$<$ Grade 9 & 41 & 18.5 & 7 \\
\hline Grade 9-11 & 93 & 41.9 & 6 \\
\hline$\geq$ Grade 12 & 87 & 39.2 & 3 \\
\hline
\end{tabular}

Table 2: HIV/STI management in affirmative responses

\begin{tabular}{|l|r|r|}
\hline & $\mathrm{N}=18$ & $\%$ \\
\hline 1. Do you know where you can obtain voluntary HIV counseling and testing services? & 16 & 88.9 \\
\hline 2. Did you refer a patient for HIV testing in the past 3 months? & 16 & 88.9 \\
\hline $\begin{array}{l}\text { 3. Did you do HIV/STI risk behavior assessment (e.g., ask about risky sex) in the past 3 } \\
\text { months? }\end{array}$ & 13 & 72.2 \\
\hline $\begin{array}{l}\text { 4. Did you do HIV/STI risk reduction counseling (e.g., advice on condom use, } \\
\text { abstinence, fidelity \& partner reduction) in the past 3 months? }\end{array}$ & 16 & 88.9 \\
\hline 5. Did you integrate partner referral in your STD treatment in the past 3 months? & 15 & 83.3 \\
\hline 6. Did you distribute condoms in the past 3 months? & 14 & 77.8 \\
\hline 7. Did you do HIV/AIDS/STI community education in the past 3 months? & 11 & 61.1 \\
\hline 8. Did you do home-based care in the past 3 months? & 7 & 38.9 \\
\hline 9. Did you keep records of patients in the past 3 months? & 13 & 72.2 \\
\hline
\end{tabular}

\section{Case study of a THP practice and training impact}

The one THP who has his practice right in the middle of town in Durban also gets a lot of HIV positive clients. His practice is well organized, just like a doctor's one. He even has a well organized dispensary where they also package staff for postage. He has clients from all over the country. He is very humble one can never say that it's him who is so powerful when you see him. He has his own programme where he monitors the CD4 count and the viral load of his clients. The Department of Health has come to check the documents of his clients so as to see how true it is that the viral load becomes undetectable. He says the bad thing is that they took the documents and never brought them back. He requests his clients to check their CD4 count and viral load before they start with his medication and after every three months of starting with the medication. This is the THP who was saying that people who take his medication become HIV negative. During the training we made him understand the difference between 
being HIV positive and the viral load that is undetectable. The viral load of many clients who use his medication become undetectable after sometime. Many of his clients were coming as couples as he encourages them to support each other.

\section{HIV risk practices at the workplace}

Most traditional health practitioners indicated that they had performed incisions or scarifications and half used an enema on their patients in the past three months. Use of enema contaminated equipment and razor blade can serve as routes of infection from one client to the next, hence the importance of using new razor blades and sterilized enema equipment. Three (17\%) had reused enema equipment without sterilization in the past three months, $24 \%$ used the same razor blade for scarifications on more than one patient and $29 \%$ did not use gloves when carrying out scarifications (Table 3).

Table 3: HIV risk practices at the work place in affirmative responses

\begin{tabular}{|l|l|}
\hline & $\begin{array}{l}\text { Healers } \\
(\mathrm{n}=17)\end{array}$ \\
\hline Level of practice & $\mathrm{N}$ \\
\hline $\begin{array}{l}\text { 1. Did you perform incisions or scarifications at least once on a patient in the } \\
\text { past 3 months? }\end{array}$ & 12 \\
\hline 2. Did you use an enema at least once with a patient in the past 3 months? & 8 \\
\hline HIV risk practice & 3 \\
\hline 1. Did you reuse enema equipment without sterilization in the past 3 months? & 3 \\
\hline $\begin{array}{l}\text { 2. Did you use the same razor blade to perform incisions or scarifications on } \\
\text { more than one patient in the past 3 months? }\end{array}$ & 4 \\
\hline $\begin{array}{l}\text { 3. Did you use gloves when carrying out incisions or scarifications in the past } \\
\text { 3 months? (reverse coded) }\end{array}$ & 12 \\
\hline 4. Did you reuse gloves with patients in the past 3 months? & 2 \\
\hline 5. Did you use boiled water for reusable instruments? & 8 \\
\hline
\end{tabular}

\section{Illness presentation}

Major self-reported reasons for consulting the THP included a complex of supernatural problems (bad luck, reverse bad luck, magic poisoning) or psychosocial problems (depression, anxiety, sexual dysfunction), chronic conditions (chronic pain in joints/arthritis, hypertension, diabetes, cancer), acute conditions, generalized pain,HIV and other STIs (Table 4). Almost half of the patients (45\%) patients indicated that they had been for the current illness episode to a different health care agent prior to coming to this THP.

Clients were further asked for which type of problems they had been previously consulting a THP. Similar to the current illness episode, clients reported the following five problem areas, in order of frequency:

1) a complex of supernatural or psychosocial problems (reverse bad luck, bad luck, magic poisoning by stepping over something, being poisoned by food purposely, ancestral problem, spirit illness, mental problems), 2) generalized pain (headache, sharp pains), 3) acute conditions (stomach problems, sores/shingles), 4) HIV and other STIs, and 5) chronic conditions (arthritis, high blood pressure/heart problems, diabetes mellitus, cancer) (Table 5).

\section{HIV positive patients and Antiretroviral Therapy (ART)}

Eighteen patients reported that they consulted the traditional health practitioner because of HIV/AIDS, 15 were female and 3 were male; half (9) were between 26-35 years old. They were asked whether they had received HIV related services, 9 reported to have discussed safer sex, 8 family planning, 7 were provided with condoms, and 5 were referred for further management to a biomedical health facility. 
Table 4: Illness in consultation with traditional health practitioner

\begin{tabular}{|l|r|r|}
\hline & $\mathrm{N}$ & $\%$ \\
\hline Bad luck, reverse bad luck & 47 & 21.2 \\
\hline Acute conditions (diarrhea, fever, flu, headaches, cough, other) & 41 & 18.5 \\
\hline Generalized pain (stomach, muscle or other nonspecific pain) & 30 & 13.5 \\
\hline Chronic pain in your joints/arthritis (joints, back, neck) & 27 & 12.2 \\
\hline Psychosocial problem (marital, mental, ancestors problems; spirit illness) & 27 & 12.2 \\
\hline Magic poisoning & 25 & 11.3 \\
\hline Problems with your breathing & 21 & 9.5 \\
\hline Communicable disease: HIV & 18 & 8.1 \\
\hline Infertility & 16 & 7.2 \\
\hline Children's problems & 13 & 5.9 \\
\hline Weakness of the body, dizziness & 12 & 5.4 \\
\hline Communicable disease: STI (other than HIV) & 11 & 5.0 \\
\hline Other & 8 & 3.6 \\
\hline High blood pressure / hypertension & 4 & 1.8 \\
\hline Diabetes or related complications & 4 & 1.8 \\
\hline Epilepsy & 3 & 1.4 \\
\hline Cancer & 3 & 1.4 \\
\hline Depression or anxiety & 3 & 1.4 \\
\hline Stroke/sudden paralysis of one side of body & 2 & 0.9 \\
\hline Problems with your mouth, teeth or swallowing & 2 & 0.9 \\
\hline Sexual dysfunction & 2 & 0.9 \\
\hline
\end{tabular}

Table 5: Condition or problem for previous health care seeking with a THP (multiple response possible)

\begin{tabular}{|l|l|c|c|}
\hline English & Zulu & $\mathbf{N}$ & $\begin{array}{l}\text { \% of } \\
\text { cases }\end{array}$ \\
\hline 1. Headache & Ikhanda elibuhlungu & 92 & 41.4 \\
\hline 2. Reverse bad luck & Ukulahla isilwane/ Ukubethela & 58 & 26.1 \\
\hline 3. Bad luck & Isichitho & 56 & 25.2 \\
\hline 4. Sharp pains & Izibhobo/amahlaba & 52 & 23.4 \\
\hline 5. Magic poisoning by stepping over something & Umeqo & 50 & 22.5 \\
\hline 6. Ancestral problems & Amandiki & 42 & 18.9 \\
\hline 7. Sexually transmitted infections & Izifo zocansi & 33 & 14.9 \\
\hline 8. Stomach problems & Isisu & 31 & 14.0 \\
\hline 9. Children's problems & Izigulo zezingane & 27 & 12.2 \\
\hline 10. Infertility & Inzalo/isihlambezo & 26 & 11.7 \\
\hline 11. Chest problems & Isifuba & 24 & 10.8 \\
\hline 12. Spirit illness & Ukuthwasisa & 21 & 9.5 \\
\hline 13. Being poisoned by food purposely & Idliso & 20 & 9.0 \\
\hline 14. Sores/shingles & Izilonda/ibhande & 19 & 8.6 \\
\hline 15. Arthritis & Isifo samathambo & 17 & 7.7 \\
\hline 16. HIV/AIDS & Isandulela ngculazi/ingculazi & 14 & 6.3 \\
\hline 17. High blood pressure/heart problems & Isifo senhliziyo & 9 & 4.1 \\
\hline 18. Stroke & Unhlangothi & 8 & 3.6 \\
\hline 19. Diabetes Mellitus & Isifo sikashukela & 7 & 3.2 \\
\hline 20. Mental problems & Ukugula Ngengqonda & 5 & 2.3 \\
\hline 21. Epilepsy & Isifo sokuwa & 5 & 2.3 \\
\hline 22. Cancer & Isifo somdlavuza & 5 & 2.3 \\
\hline 23. Other & & 61 & 27.5 \\
\hline
\end{tabular}


Twelve of the 18 HIV patients were on ART and six not on ART; all were using traditional medicine for HIV, HIV related illnesses or ART side effects; 12 were using traditional medicine and ART concurrently. Two patients had been on ART but had stopped because of side effects. The THPs advised them to go back on ART. Eleven HIV patients were using some form of contraception. Some case examples for different types of HIV management by the THP are described below:

\section{Case 1: Referral for HIV testing}

The one client was saying that she became sick without knowing that she was HIV positive. Her family took her to the THP who then advised them to take her to the hospital so that they can also request that she be tested for HIV. She is so grateful today because she believes if she was not tested she could have been too sick and may have progressed to AIDS sooner. Her CD4 count was still greater than 200 when she tested positive. She is now taking good care of herself and is not sick. She still visits the THP for support and the bottle (traditional medicine for HIV); she is not on ART.

\section{Case 2: HIV-related illness}

This female patient has been on ART for a long time and was due for an operation for a hip replacement. She was then advised by someone about this THP who can save her from the operation. She then went to see the THP now for the $3^{\text {rd }}$ time. The effects of ARVs caused her to not being able to walk but she said after using this THP's medication she could walk using walking stick. She was hopeful that if she continues with his medication she would eventually walk without the stick.

\section{Case 3: Side effects of ART}

This female client indicated when consulting the THP that she wanted to stop taking ARVs. She had been taking traditional medicine for HIV before starting with the ARVs. The THP advised her to go back on ART. She was frustrated because when she was taking the THP's medication alone she didn't have any side effects but when she was using ARVs she started having problems. She is now on ART and taking traditional medicine for side effects of ART.

\section{Case 4: Traditional medicine and ART}

This client explained how she started with the ARVs. She said the THP took her to the hospital to test for HIV. When she tested HIV positive, he suggested that he must check her CD4 count and viral load. Her CD4 count was less than 200 and the THP suggested to her that she should start with ARVs. She agreed but she was frustrated when she was told she would be put on the waiting list. She had expected to get ARVs there. The THP explained to her that she must be patient, she continued with the THP's medication until the hospital was ready to give her the ARVs. She said if it wasn't because of the support from the THP she would have given up on the ARVs. She was then advised not to take anything else other than the ARVs or whatever that was from the hospital only. She was depressed by this as she didn't want to stop the THP's medication. She stopped it and took the ARVs only but she became very sick from the side effects. She then just went back to her "bottle" and she became better. The THP's medication helps her with the ARVs' side effects.

\section{Case 5: AIDS management}

The one client in Pietermaritzburg explained to us that when he was brought to that THP he was from the hospital. He had been discharged from the hospital to go and die at home; not being on ART. His sister heard about this THP and took him to him. He said after a week of using his "bottle" he could stand on his own and was feeling stronger. At the time when he was interviewed he had come for his follow up and one could not believe he was ever as sick as he was describing his sickness. The THP witnessed that he also could not believe when he saw him for the second time. 


\section{AIDS treatment knowledge}

Overall, patients including HIV positive patients had moderate knowledge of ART, with a good number supporting myth or misconception about ART. Comparing patients, HIV positive patients and THPs regarding AIDS treatment knowledge it appears that overall THPs had higher knowledge of ART than their patients including HIV patients (see Table 6).

Table 6: AIDS treatment knowledge in affirmative responses

\begin{tabular}{|c|c|c|c|}
\hline & \multicolumn{2}{|c|}{ Patients } & \multirow{2}{*}{$\begin{array}{c}\text { Healers } \\
(\mathrm{n}=17)\end{array}$} \\
\hline & $\begin{array}{l}\text { Patients } \\
(\mathbf{n}=222)\end{array}$ & $\begin{array}{l}\text { HIV + } \\
(n=18)\end{array}$ & \\
\hline & $\%$ & $\%$ & $\%$ \\
\hline 1. Do you know a health facility that offers ART? & 71.2 & 72.2 & 88.2 \\
\hline $\begin{array}{l}\text { 2. Do you know that ART requires that you need to disclose your HIV } \\
\text { status to a close friend or relative as a treatment supporter. }\end{array}$ & 82.4 & 88.9 & 88.2 \\
\hline $\begin{array}{l}\text { 3. Once you start with ART you will have immediate improvement in your } \\
\text { health from the start of treatment. }\end{array}$ & 56.3 & 33.3 & 76.5 \\
\hline 4. Is ART effective? & 68.0 & 61.1 & 88.2 \\
\hline 5. AIDS is a deadly disease, so ART cannot do anything. & 41.4 & 22.2 & 64.7 \\
\hline 6. Does ART cure AIDS? & 15.8 & 5.6 & 5.9 \\
\hline 7. ART blocks the disease's children from reproducing. & 48.6 & 44.4 & 58.8 \\
\hline 8. ART can also be given to children? & 41.4 & 38.9 & 52.9 \\
\hline 9. ART is not safe since the government may stop the treatment. & 18.0 & 11.1 & 23.5 \\
\hline $\begin{array}{l}\text { 10. When on ART external symptoms of HIV disease such as weight loss, } \\
\text { dermatological lesions or "spots" or diarrhoea. }\end{array}$ & 51.8 & 55.6 & 70.1 \\
\hline $\begin{array}{l}\text { 11. There are people who want to take ART but their bodies cannot handle } \\
\text { it. }\end{array}$ & 68.2 & 77.8 & 88.2 \\
\hline 12. ART needs to be taken twice a day. & 36.9 & 50.0 & 47.1 \\
\hline 13. ART has to be taken at least $95 \%$ of the times. & 19.8 & 11.1 & 23.5 \\
\hline 14. Women can become infertile from ART. & 18.0 & 11.1 & 23.5 \\
\hline 15. Men can become sterile from ART. & 18.0 & 11.1 & 52.9 \\
\hline 16. Men become sexually impotent from ART. & 23.9 & 11.1 & 47.1 \\
\hline 17. People on ART have revived sexual desire. & 41.9 & 38.9 & 47.1 \\
\hline 18. An HIV positive woman must not have children. & 50.1 & 38.9 & 52.9 \\
\hline $\begin{array}{l}\text { 19. The effectiveness of ART reduces overtime since ART is taken } \\
\text { continuously and saturates in the body. }\end{array}$ & 38.3 & 22.2 & 47.1 \\
\hline 20. When on ART one does not need to use a condom. & 18.0 & 5.6 & 23.5 \\
\hline $\begin{array}{l}\text { 21. The side effects of ART are a sign of the strength of the medicine, } \\
\text { "taking out" the illness. }\end{array}$ & 50.4 & 38.9 & 64.7 \\
\hline
\end{tabular}

\section{Discussion}

This study found that from 222 patients when exiting a full-time traditional health practitioners practice $(\mathrm{n}=17)$ in two urban sites (Durban and Pietermaritzburg) in KwaZulu-Natal, South Africa, $80 \%$ were female, 59.4\% were between 18 to 35 years old, and $81 \%$ had Grade 9 and more education and for $65 \%$ of them it took 45 mins and less to get to the THP. In concurrence with other studies (e.g. Ahmed et al., 1999; Devisch, 1993; Peltzer, 1987) this study found that the majority of those seeking the help of THPs were women. Unlike other studies (Berhane et al., 2001; Peltzer, 1987), this study found that also young and educated participants in this urban area consulted THPs.

Major self-reported reasons for consulting the THP included a complex of supernatural problems or psychosocial problems, chronic conditions, acute conditions, generalized pain, HIV and other STIs. This study found that the most common reason for consulting the THP in this urban setting was a complex of supernatural problems (bad 
luck, reverse bad luck, magic poisoning, ancestral problems). Most of the participants being African women ( $80 \%)$ may imply an emphasis on the spiritual influences that touch their daily lives thereby leading them to seek THP rather than modern health services (Nelms and Gorski, 2006). Unlike in other studies (Nelms and Gorski, 2006; Peltzer, 1987) this study found that in this urban region where women are better educated and exposed to other influences such as the media there was still emphasis on spiritual causes of illness.

In the study, 8 of the $18 \mathrm{HIV}$ positive patients were using traditional medicine and ART concurrently and eight were using traditional medicine for HIV and HIV-related illnesses. Mills et al. (2006) note that in Africa, herbal medicines are, at times, used as primary treatment for HIV/AIDS and for HIV-related problems including dermatological disorders, nausea, depression, insomnia and weakness. Some authors (e.g. Nyika, 2007) have indicated that the concomitant use of ART and traditional medicine could compromise adherence as one may switch from one to the other at certain times and possible negative effects of interactions between some traditional herbs and ARVs. Overall, the study found that patients including HIV positive patients had moderate knowledge of ART, with a good number supporting myth or misconception about ART. Nachega et al. (2005) found among 105 HIV infected patients in Soweto still lower knowledge of ART than in this study, e.g. HIV can be cured by ART was endorsed by $51 \%$ of the patients in Soweto compared to $6 \%$ among HIV patients and $16 \%$ among general patients in this study. Comparing patients, HIV positive patients and THP regarding AIDS treatment knowledge it appears that overall THPs had higher knowledge of ART than their patients including HIV patients.

The study found that THP play a role in HIV prevention and care in terms of having referred a patient for HIV testing, conducting HIV/STI risk behavior assessment, integrating partner referral in their STD management, conducting HIV/STI risk reduction counseling, had distributed condoms to their patients and conducting community HIV/AIDS/STI education. THPs have been shown to be effective HIV/AIDS educators, counsellors, and sources of referrals (Green et al., 1995; King and Homsy, 1997; Peltzer et al., 2006). Although all THP in this study had been specifically trained on HIV/AIDS/STI some still engaged in HIV risk practices such as reuse of enema equipment without sterilization, use of the same razor blade for scarifications on more than one patient and did not use gloves when carrying out scarifications. Communities, THP clients and THP should be further trained/empowered in the following minimum aspects of HIV prevention and care: Cultural beliefs and practices; Basic and updated information on prevention and care for STDs, HIV/AIDS, and tuberculosis; Infection control; Identification of danger signs to enable THPs to make referrals; Integration of biomedical and traditional counselling approaches on STDs, HIV/AIDS, and TB, including client couselling, support and referral (Homsy et al., 2004).

In urban African settings patients often choose traditional health systems as primary care including HIV treatment and will continue to access these systems even in urban settings because they are consistent with local cultural values and beliefs. THPs represent a large and important health-care resource, potentially capable of expanding access to HIV education and counseling. This, coupled with the difficulties in accessing antiretroviral treatment and its side effects, justifies further efforts to determine the scope of traditional medicine use, identifies the negative consequences of this practice, and evaluates the benefits of herbal remedies (Mills et al., 2006).

\section{Acknowledgements}

Funding was provided by Bristol-Myers Squibb Foundation (Secure the Future Programme) and the Human Sciences Research Council, South Africa. Support was given by the KwaZulu-Natal Health Department and the KwaZulu-Natal Traditional Health Practitioners Council. Thanks to Dorothy Buthelezi and Margaret Shangase who assisted in accessing the traditional health practitioners and data collection.

\section{References}

1. Ahmed, M.I., Bremer, J.J., Magzoub, M.M.E. and Nouri, A.M.H. (1999). Characteristics of visitors to traditional healers in central Sudan. Eastern Mediterranean Hlth J., 5(1): 79-85.

2. Berhane, Y., Gossaye, Y., Emmelin, M. and Hogberg, U. (2001.) Women's health in a rural setting in societal transition in Ethiopia. Social Sci. Med., 53: 1525-1539.

3. Department of Health (2004). Operational plan for comprehensive HIV and AIDS care, management and treatment for South Africa. Pretoria: Department of Health.

4. Desclaux, A., Laniece, I., Nodoye, I., and Taverne, B. (2004). The Senegalese antiretroviral drug access initiative: an economic, social, behavioural and biomedical analysis. Paris: ANRS, UNAIDS, WHO. 
5. Devisch, R. (1993). Weaving the threads of life: the Kita gen-eco-logical healing cult among the Yaka. Chicago. University of Chicago Press.

6. Freeman, M. and Motsei, M. (1992). Planning health care in South Africa: is there a role for traditional healers? Social Sci. Med. 34: 1183-1090.

7. Green, E. (1994). AIDS and STDS in Africa: Bridging the gap between traditional healers and modern medicine. Boulder: Westview Press.

8. Green, E., Zokwe, B., and Dupree, J. (1995). The experience of an AIDS prevention program focused on South African traditional healers. Social Sci. Med., 40: (4), 503-515.

9. Homsy, J., King, R., Tenywa, J., Kyeyune, P., Opio, A., and Balaba, D. (2004). Defining minimum standards of practice for incorporating African traditional medicine into HIV/AIDS prevention, care, and support: a regional initiative in Eastern and South Africa. The J. Altern. Complementary Med., 10(5): 905-910.

10. King, R. and Homsy, J. (1997). Involving traditional healers in AIDS education and counseling in sub-Saharan Africa: A review. AIDS, 11(Suppl A), S217-225.

11. Louw, D.A. and Pretorius, E. (1995). The traditional healer in a multicultural society: the South African experience. In: L.L. Adler \& B.R. Mukherji (Eds.) Spirit versus scalpel: traditional healing and modern psychotherapy (pp. 41-58). London: Bergin \& Garrey.

12. Mills, E., Cooper, C. and Kanfer, I. (2005) Traditional African medicine in the treatment of HIV. The Lancet, 5: 465-467.

13. Mills, E., Singh, S., Wilson, K., Peters, E., Onia, R. and Kanfer, I.. (2006) The challenges of involving traditional healers in HIV/AIDS care. Intern. J. STD AIDS, 17: 360-3.

14. Nachega, J.B., Lehman, D.A., Hlatshwayo, D., Mothopeng, R., Chaisson, R.E., and Karsteadt, A.S. (2005). HIV/AIDS and antiretroviral treatment knowledge, attitudes, beliefs, and practices in HIV-infected adults in Soweto, South Africa. J. Acquired Immune Deficiency Syndrome, 38(2): 196-201.

15. Nelms, L.W. and Gorski, J. (2006) The role of the African healer in women's health. J. Transcultural Nursing, 17: 184-189.

16. Nyika, A. (2007) Ethical and regulatory issues surrounding African traditional medicine in the context of HIV/AIDS. Developing World Bioethics, 7(1): 25-34.

17. Peltzer, K. (1987). Traditional healing and psychosocial health care in Malawi. Heidelberg: Asanger

18. Peltzer, K. (1998). A community survey of traditional healers in rural South Africa. South African J. Ethnology, 21: 191-197.

19. Peltzer, K. (2000). Perceived treatment efficacy of the last experienced illness episode in a community sample in the Northern Province, South Africa. Curationis, 23(1): 57-60.

20. Peltzer, K. (2001). An investigation into practices of traditional and faith healers in an urban setting in South Africa. Health SA Gesondheid, 6(2): 3-11.

21. Peltzer, K. (2003). HIV/AIDS/STD knowledge, attitudes, beliefs and behaviours in a rural South African adult population. South African J. Psychology, 33(4): 250-260.

22. Peltzer, K., Mngqundaniso, N. and Petros, G. (2006a) A controlled study of an HIV/AIDS/STI/TB intervention with traditional healers in KwaZulu-Natal, South Africa. AIDS Behavior, 10: 683-690.

23. Peltzer, K., Mngqundaniso, N. and Petros, G. (2006b) HIV/AIDS/STI/TB knowledge, beliefs and practices of traditional healers in KwaZulu-Natal, South Africa. AIDS Care, 18(6): 608-613.

24. Shisana, O., Rehle, T., Simbayi, L.C., Parker, W., Zuma, K., Bhana, A., Connolly, C., Jooste, S., Pillay, V., et al.. (2005) South African National HIV Prevalence, HIV Incidence, Behaviour and Communication Survey, 2005. Cape Town: HSRC Press

25. Somsé, P., Chapko, M.K., Wata, J.B., Bondha, P., Gonda, B., Johnson, D., Downer, A., and Kimball, A.M. (1998). Evaluation of AIDS training program for traditional healers in the Central African Republic. AIDS Education and Prevention, 10(6): 558-64.

26. UNAIDS (2002). Ancient remedies, new disease: Increasing access to AIDS prevention and care in collaboration with traditional healers. Geneva: UNAIDS Best Practices Collection.

27. UNAIDS (2006) Collaborating with traditional healers for HIV prevention and care in sub-Saharan Africa: suggestions for programme managers and field workers. Geneva: UNAIDS.

28. Wilkinson, D. and Wilkinson, N. (1998). HIV infection among patients with sexually transmitted diseases in rural South Africa. Intern. J. STD AIDS, 9(12): 736-9. 